\title{
Book Review \\ THE TAO OF ISLAM \\ (Kitab Rujukan tentang Relasi Gender dalam Kosmologi dan Teologi Islam)
}

\author{
Romdloni ${ }^{1}$ \\ Dosen STKIP Nurul Huda OKU Timur \\ Email: romdlony29@gmail.com
}

\begin{abstract}
ABSTRAK
Perbincangan masalah gender, seringkali menimbulkan suasana yang "kurang nyaman" bahkan konfrontatif, baik dalam forum perempuan saja maupun forum yang melibatkan laki-laki dan perempuan. Hal ini karena gender dianggap sebagai sesuatu yang Baratsentris. Bahkan seringkali terjadi kerancuan pandangan tentang konsep seks dan gender, baik oleh laki-laki maupun perempuan sendiri. Gender masih identik dengan perempuan. Karena itu, persoalan gender juga adalah persoalan perempuan. Padahal sebenarnya, persoalan gender adalah problem bersama laki-laki dan perempuan, karena menyangkut peran, fungsi, dan relasi antara kedua jenis kelamin tersebut, baik kehidupan ranah domestik maupun publik. Gender secara umum digunakan untuk mengidentifikasi perbedaan laki-laki dan perempuan dari segi sosial-budaya. Studi gender lebih menekankan perkembangan aspek maskulinitas (masculinity/rujuliyah) atau feminitas (feminity/nisa'iyyah) seseorang. Berbeda dengan studi seks yang lebih menekankan perkembangan aspek biologis dan komposisi kimia dalam tubuh laki-laki (maleness/zhukurah) dan perempuan (femaleness/unutsah). Untuk proses pertumbuhan anak menjadi seorang laki-laki atau perempuan, lebih banyak digunakan istilah gender daripada istilah seks. Istilah seks umumnya digunakan untuk merujuk kepada persoalan reproduksi dan aktivitas seksual, selebihnya digunakan istilah gender
\end{abstract}

Key word: gender, kosmologi, teologi Islam

\section{PENDAHULUAN}

Efek globalisasi yang mengikis batas geografis dan ideologis kini sangat nyata, gerakan gender equelity yang dikampanyekan di barat, kini sudah mengehembus ke timur. Gerakan yang menuntut kesetaraan hak perempuan sejajar dengan kaum Adam tumbuh subur diberbagai tempat. Lagi-lagi agama yang dinilai mapan harus menjadi objek perdebatan. Contoh kecil misalnya, persoalan waris harus ditinjau ulang, pasalnya karena diskriminatif, tidak mengusung nilai keadilan dan persamaan. Pada akhirnya Islam menjadi kambing hitam karena dianggap memposisikan perempuan sebagai manusia kelas dua.

Problem tentang relasi gender selalu mengemuka dan setiap individu atau kelompok memiliki pendekatan sendiri-sendiri sehingga melahirkan pandangan yang berbeda-beda. Di penghujung abad ke-20, telah terjadi perubahan paradigma berpikir dalam melihat pola relasi gender. Antara tahun 1960 dan 1970-an, gerakan feminisme di Barat banyak dipengaruhi oleh filsafat eksistensialisme yang berkembang terutama oleh filosof Jean Paul Sartre. Sartre berpendapat bahwa manusia tidak mempunyai fitrah atau esensi (innate nature). Eksistensi manusia tergantung pada bagaimana dia menciptakan esensinya sendiri, dan yang dimaksud dengan esensi manusia adalah socially created yaitu tergantung dengan lingkungan di mana dirinya berada. Pemahaman di atas diterapkan oleh Simone de Beauvoir dalam menolak eksistensi sifat alami perempuan dan laki-laki. Dalam bukunya, The Second Sex, Simone de Beauvoir mengatakan bahwa perempuan secara kultural diperlakukan sebagai mahluk sekunder (secondary creation)

${ }^{1}$ Dosen Prodi PAI STKIP Nurul Huda OKU Timur, makalah ini disajikan saat penulis masih menempuh studi S2 di UIN Maulana Malik Ibrahim Malang. 
yang tugasnya mengasuh keluarga dan anaknya, serta memelihara lingkungan hidup. Dia menyebutkan bahwa norma-norma feminin yang selama ini dilekatkan pada perempuan, seperti pengasuh, pemelihara, pasif dan penerima merupakan sifat yang dikulturkan oleh sistem patriarkhi. ${ }^{2}$

Konsep keseimbangan terdapat pada kebudayaan yang tidak memanifestasikan Tuhan dalam wujud konkret, dalam hal ini adalah kebudayaan Islam. Walau tidak memiliki wujud konkret, namun konsep keseimbangan gender dalam hal ketuhanan yang dikenal Islam terdapat pada sifat-sifat Tuhan yang terdapat di nama-nama-Nya (asmaul husna). Mengutip Ibnu Arabi, Sachiko Murata (1992), seorang ahli di bidang perbandingan agama, dalam buku The Tao Of Islam melihat bahwa ada sifat feminin di nama-nama seperti al-Quddus (suci), dan ar-Rahiim (penyayang); juga sifat maskulin di nama-nama seperti al-Aziz (perkasa) dan al-Jabbar (penguasa). Muslimah Jepang ini telah mengupas habis diskursus relasi gender ini dalam bukunya The Tao of Islam dengan lebih objektif dan komprehensif.

\section{PENGERTIAN GENDER}

Kata Gender berasal dari bahasa Inggris berarti "jenis kelamin". ${ }^{3}$ Dalam Webster's New World Dictionary, gender diartikan sebagai perbedaan yang tampak antara laki-laki dan perempuan dilihat dari segi nilai dan tingkah laku. ${ }^{4}$ Di dalam Women's Studies Encyclopedia dijelaskan bahwa gender adalah suatu konsep kultural yang berupaya membuat pembedaan (distinction) dalam hal peran, perilaku, mentalitas, dan karakteristik emosional antara laki-laki dan perempuan yang berkembang dalam masyarakat. 5

Ivan Illich ${ }^{6}$ mendefinisikan gender dengan pembeda-bedaan tempat, waktu, alatalat, tugas-tugas, bentuk pembicaraan, tingkah laku dan persepsi yang dikaitkan dengan perempuan dalam budaya sosial. ${ }^{7}$

Hillary M. Lips dalam bukunya yang terkenal Sex \& Gender: an Introduction mengartikan gender sebagai harapan-harapan budaya terhadap laki-laki dan perempuan (cultural expectations for women and men). Pendapat ini sejalan dengan pendapat umumnya kaum feminis seperti Linda L. Lindsey, yang menganggap semua ketetapan masyarakat prihal penentuan seseorang sebagai laki-laki atau perempuan adalah termasuk bidang kajian gender (What a given society defines as masculine or feminine is a component of gender). H.T. Wilson dalam Sex and Gender mengartikan gender sebagai suatu dasar untuk menentukan perbedaan sumbangan laki-laki dan perempuan pada kebudayaan dan kehidupan kolektif yang sebagai akibatnya mereka menjadi laki-laki dan perempuan. Elani Showalter mengartikan gender lebih dari sekedar pembedaan laki-laki dan perempuan dilihat dari konstruksi sosial-budaya. Ia

${ }^{2}$ Ratna Megawangi, "Sekapur Sirih" dalam Sachiko Murata, The Tao of Islam: Kitab Rujukan tentang Relasi Gender dalam Kosmologi dan Teologi Islam, terj. Rahmani Astuti dan M. S. Nasrullah (Bandung: Mizan, 1998), hlm. 7.

${ }^{3}$ John M. Echols dan Hassan Shadily, Kamus Inggeris Indonesia, cet. XII (Jakarta:Gramedia, 1983), hlm. 265.

${ }^{4}$ Victoria Neufeldt (ed), Webster's New World Dictionary (New York: Webster's New World Clevenlan, 1984), hlm. 561.

${ }^{5}$ Helen Tierney (ed), Women's Studies Encylopedia, vol. I (New York: Green Wood Press), hlm. 153.

${ }^{6}$ Illich dianggap sebagai orang yang pertama menggunakan istilah gender dalam analisis ilmiahnya untuk membedakan segala sesuatu di dalam masyarakat yang tidak hanya terbatas pada penggunaan jenis kelamin semata. Lihat Siti Ruhaini Dzuhayatin, "Gender dalam Persfektif Islam: Studi terhadap Hal-hal yang Menguatkan dan Melemahkan Gender dalam Islam", dalam Mansour Fakih et al, Membincang Feminisme: Diskursus Gender Perspektif Islam, cet. I (Surabaya: Risalah Gusti, 1996), hlm. 23.

${ }^{7}$ Ivan Illich, Gender, diterjemahkan oleh Omi Intan Naomi dengan judul Gender, cet. I (Yogyakarta: Pustaka Pelajar, 1998), hlm. 3. 
menekankannya sebagai konsep analisis yang dapat digunakan untuk menjelaskan sesuatu. 8

Zaitunah Subhan mengemukakan bahwa yang dimaksud gender adalah konsep analisis yang dipergunakan untuk menjelaskan sesuatu yang didasarkan pada pembedaan laki-laki dan perempuan karena konstruksi sosial budaya. ${ }^{9}$

Pengertian yang lebih kongkrit dan lebih operasioanal dikemukakan oleh Nasaruddin Umar bahwa gender adalah konsep kultural yang digunakan untuk memberi identifikasi perbedaan dalam hal peran, prilaku dan lain-lain antara laki-laki dan perempuan yang berkembang di dalam masyarakat yang didasarkan pada rekayasa sosial. ${ }^{10}$

\section{PERBEDAAN SEX DAN GENDER}

Pengertian gender sering disinonimkan dengan pengertian sex, yakni jenis kelamin, padahal keduanya memiliki perbedaan yang mendasar. Sex (jenis kelamin) merupakan pensifatan atau pembagian jenis kelemin yang ditentukan secara biologis dan melekat pada kelamin tertentu secara permanen yang mengambil bentuk laki-laki dan perempuan dan tidak dapat dipertukarkan.

Yang dimaksud dengan tidak dapat dipertukarkan adalah bahwa jika laki-laki bertukar seks dengan jenis kelamin perempuan, maka ia akan tetap saja tidak bisa melakukan tugas reproduksi sebagaimana perempuan, karena ia tidak memiliki rahim dan sel telur, meskipun memiliki alat kelamin perempuan (vagina). Demikian juga seorang perempuan yang mengganti jenis kelaminnya dengan laki-laki, maka meskipun ia memiliki alat kelamin laki-laki (penis), namun tetap saja tidak bisa membuahi, karena ia tidak memiliki spermatozoa. ${ }^{11}$

Adapun gender secara umum digunakan untuk mengidentifikasi perbedaan lakilaki dan perempuan dari segi sosial-budaya. Studi gender lebih menekankan perkembangan aspek maskulinitas (masculinity/rujuliyah) atau feminitas (feminity/nisa'iyyah) seseorang. Berbeda dengan studi seks yang lebih menekankan perkembangan aspek biologis dan komposisi kimia dalam tubuh laki-laki (maleness/zhukurah) dan perempuan (femaleness/unutsah). Untuk proses pertumbuhan anak menjadi seorang laki-laki atau perempuan, lebih banyak digunakan istilah gender daripada istilah seks. Istilah seks umumnya digunakan untuk merujuk kepada persoalan reproduksi dan aktivitas seksual, selebihnya digunakan istilah gender. ${ }^{12}$

Dahulu orang belum banyak tertarik untuk membedakan seks dan gender, karena persepsi yang berkembang dalam masyarakat menganggap perbedaan gender sebagai akibat perbendaan seks. Pembangian peran dan kerja secara seksual dipandang sebagai suatu hal yang wajar. Akan tetapi belakangan ini disadari bahwa tidak mesti perbedaan seks menyebabkan ketidakadilan gender.

\footnotetext{
${ }^{8}$ Nasaruddin Umar, Argumen Kesetaraan Jender Perspektif Al-Quran, Jakarta: Paramadina, cet. I, 1999, h. 33 .

${ }^{9}$ Lihat Zaitunah Subhan, "Gender dalam Perspektif Islam”, dalam jurnal Akademika, Vol. 06, No. 2, Maret, hlm. 128.

${ }^{10}$ Lihat Nasaruddin Umar, "Perspektif Gender dalam Islam", jurnal Paramadina, Vol. I. No. 1, JuliDesember 1998, hlm. 99.

${ }^{11}$ Umi Sumbulah, Spektrum Gender: Kilasan Inklusi Gender di Perguruan Tinggi, Malang, UIN-Malang Press, 2008, h. 7.

${ }^{12}$ Nasaruddin Umar, Op Cit, h. 36.
} 

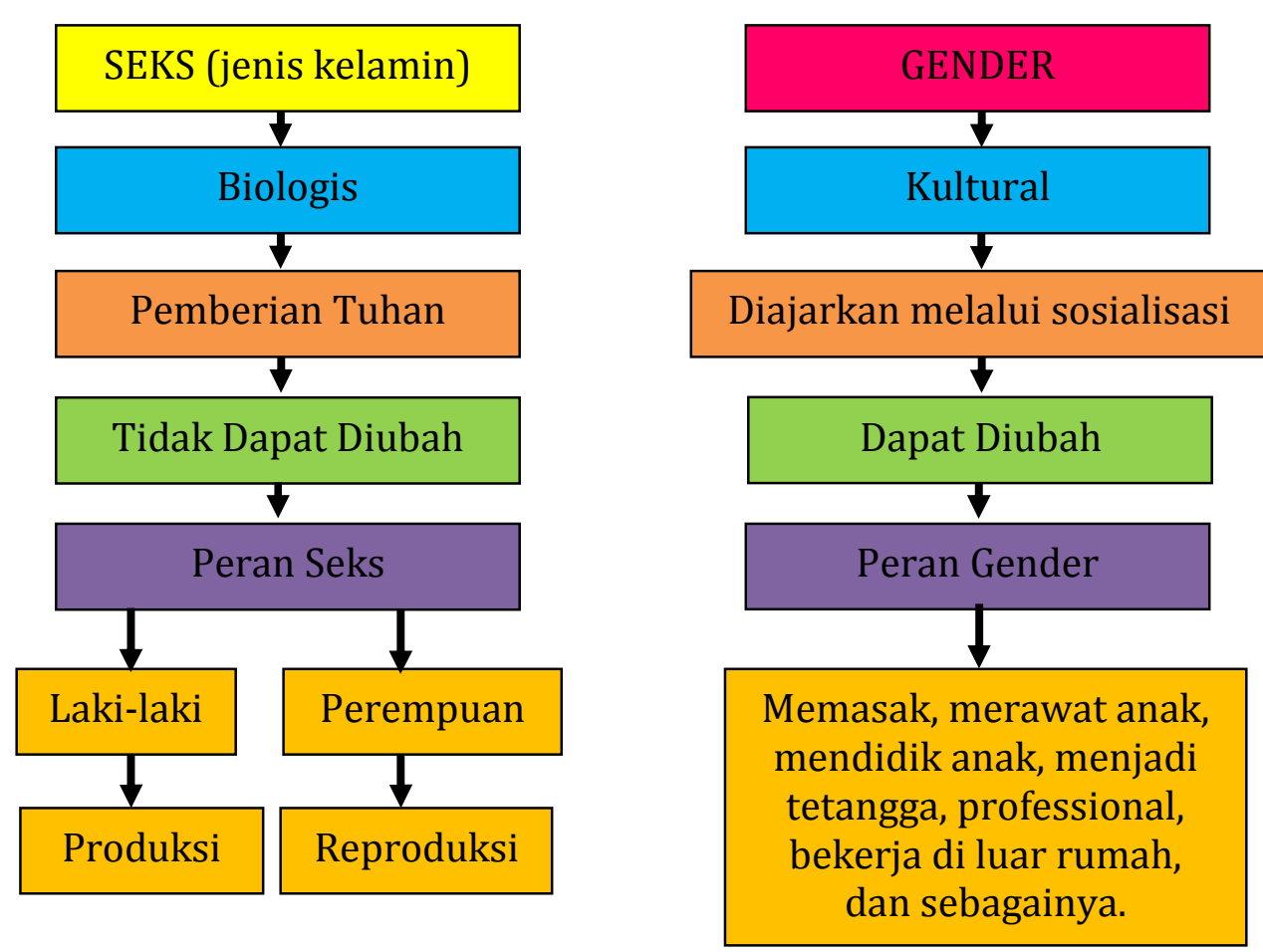

Gambar 1.

Perbedaan Seks dan Gender ${ }^{13}$

\section{GENDER DALAM ISLAM}

Dalam Islam, pengertian seks (jenis kelamin) dapat dilihat dalam penggunaan kata al-dzakar dan al-untsa di sejumlah ayat Al-Quran. Dalam tradisi bahasa Arab, kata aldzakar berakar dari kata dzal-kaf-ra berarti mengisi, menuangkan, menyebutkan, mengingat, al-dzakirah berarti mempelajari, al-dzikru jamaknya al-dzukur bermakna laki-laki atau jantan. Al-dzakar berkonotasi pada persoalan biologis (seks) sebagai lawan kata al-untsa, dalam bahasa Inggris disebut male lawan dari female, digunakan pada jenis manusia, binatang dan tumbuh-tumbuhan. Kata dzakara disebut dalam alQuran sebanyak 18 kali, lebih banyak digunakan untuk menyatakan laki-laki dilihat dari faktor biologis (seks). Sedangkan kata al-untsa berasal dari kata alif-nun-tsa berarti lemas, lembek, halus. Lafal untsa terulang sebanyak 30 kali dalam berbagai pecahannya yang pada umumnya menunjukkan jenis perempuan dan aspek biologis (seks)nya. Dengan demikian, lafal al-dzakaru dan al-untsa dipergunakan untuk menunjuk laki-laki dan perempuan dari aspek biologis (seks)nya. ${ }^{14}$

Baik definisi maupun konsep umum mengenai gender tidak disebutkan oleh alQuran secara langsung. Namun, ketika berbicara tentang gender, Al-Quran menggunkan beberapa kata yang dapat dipergunakan untuk menelaah secara kritis dalam permasalaha kesetaraan laki-laki dan perempuan dan relasi keduanya. Kata yang dipandang dekat dengan kata gender jika ditinjau dari peran fungsi dan relasi adalah kata al-rijal dan al-nisa. ${ }^{15}$

Kata al-rijal bentuk jamak dari kata al-rajul, berasal dari akar kata ra-jim-lam yang derivasinya (pecahannya) membentuk beberapa kata, seperti rajala (mengikat), rajila (berjalan kaki), al-rijl (telapak kaki), al-rijlah (tumbuh-tumbuhan), dan al-rajul (lakilaki). Dalam Lisan al-'Arab, kata al-rajul diartikan dengan laki-laki, lawan perempuan dari jenis manusia. Kata ini umumnya digunakan untuk laki-laki yang sudah dewasa,

\footnotetext{
${ }^{13}$ Mufidah Ch, Paradigma Gender, Malang: Bayumedia Publishing, Cet. I, 2003, h. 7.

${ }^{14}$ Mufidah Ch, Op Cit, h. 8.

${ }^{15}$ Ibid., h. 8 .
} 
sesuadah anak-anak. Contoh penggunaan kata al-rajul misalnya dalam QS. al-Baqarah: 282. و استشهووا شهدين من رجالكم (Dan persaksikanlah dengan dua orang saksi dari laki-laki di antaramu). Kata من رجالكم di dalam ayat ini ditafsirkan did ala Tafsir al-Jalalayn, sebagai laki-laki muslim yang akil-baligh dan merdeka. Jadi semua orang yang masuk dalam kategori al-rajul termasuk juga kategori al-dzakar. Tetapi tidak semua al-dzakar masuk dalam kategori al-rajul. Kategori al-rajul menuntut sejumlah criteria tertentu yang bukan hanya mengacu kepada jenis kelamin, tetapi juga kualifikasi budaya tertentu, terutama sifat-sifat kejantanan (masculinity). Oleh karena itu, tradisi bahasa Arab menyebut perempuan yang memiliki sifat-sifat kejantanan dengan rajlah. Al-Ishfahani mengesankan adanya perbedaan kata al-rajul dan al-dzakar. Yang pertama lebih berkonotasi gender dengan menekankan aspek maskulinitas dan kejantanan seseorang. ${ }^{16}$

Adapun kata al-nisa/النساء adalah bentuk jamak dari kata al-mar'ah/المراه/ berarti perempuan yang sudah matang atau dewasa, berbeda dengan kata untsa/الأثرك/s berarti jenis kelamin perempuan secara umum, dari yang masih bayi sampai yang sudah berusia lanjut. Kata al-nisa berarti gender perempuan, sepadan dengan kata al-rijal yang berarti gender laki-laki. Kata ini selain berarti gender perempuan juga berarti isteri (alzawj/(لزوج). Penggunaan kata al-nisa lebih terbatas daripada penggunaan kata al-rijal. Kata al-rijal bisa berarti gender laki-laki, orang, menunjuk kepada pengertian Nabi atau Rasul, tokoh masyarakat, dan budak, sedangkan kata al-nisa hanya digunakan dalam arti gender perempuan dan isteri-isteri. Pada umumnya kata al-nisa ini di dalam al-Quran digunakan untuk perempuan yang sudah berkeluarga, seperti perempuan yang sudah kawin (QS. al-Nisa:24), perempuan janda Nabi (QS. al-Nisa:22, QS. al-Ahzab:52), perempuan mantan isteri ayah (QS. al-Nisa:22), perempuan yang ditalak (QS. alBaqarah:231 dan 232), isteri yang di dzihar (QS. al-Mujadilah:2 dan 3). Kata al-nisa, sebagaimana halnya al-imra'ah tidak pernah digunakan untuk perempuan di bawah umur. Bahkan kedua kata ini lebih banyak digunakan di dalam kaitan tugas reproduksi perempuan. ${ }^{17}$

\section{BIOGRAFI SACHIKO MURATA}

Sachiko Murata adalah profesor Studi-studi agama pada Departement of

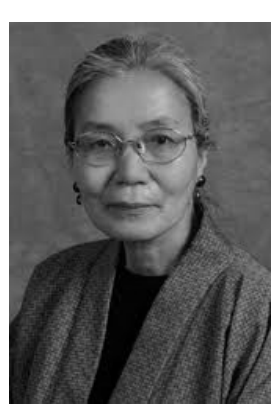
Comparative Studies di State University of New York di Stony Brook, Amerika Serikat. terkenal sebagai sufi cina melalui beberapa karya dan pemikirannya, diantaranya The Tao of Islam, Chinese Gleams of Sufi Light, The Vision of Islam dan Temporary Marriage in Islamic Law ( Nikah Sementara/Mut'ah dalam hukum Islam). Ia tumbuh seiring dengan pasang surutnya perkembangan Islam di Jepang yang sangat dipengaruhi oleh banyak hal. Informasi mengenai islam di Jepang sangat terbatas dan hanya berdasarkan stereotip Barat. Terdapatnya miskonsepsi dalam pengajaran Islam diperkenalkan oleh media Barat, dimana literatur Islam benar-benar sulit ditemui Akibatnya, kita hanya menemukan bahwa pengetahuan orang-orang Jepang mengenai Islam hanya terbatas seputar poligami, Sunni dan Syiah, Ramadhan, Mekah, Allah adalah Tuhan-nya orang Islam, dan Islam adalah agamanya Muhammad. Faktor inilah yang turut membentuk pemikiran dan tanggapan masyarakat Jepang seputar Islam, khususnya di kalangan mahasiswa .

Namun pasca peristiwa 11 September, kaum muslim jepang semakin meningkatkan aktifitas pengkajiannya baik dilembaga-lembaga maupun institusi universitas salah satunya adalah JAMES Japan Association of Middle East Studies

\footnotetext{
${ }^{16}$ Nasaruddin Umar, Op Cit, h. 144.

${ }^{17}$ Ibid., h. 163.
} 
(JAMES) dan banyak menghasilkan sarjana muslim, salah satunya adalah Sachiko Murata.

Sachiko Murata lahir di Jepang pada tahun 1943. Menyelesaikan kuliah Hukum Keluarga di Universitas Chiba Tokyo pinggiran. Selama mempelajari hukum keluarga di Jepang dalam tradisi konfusionis, beliau tertarik dengan Hukum Keluarga Islam yang berkembang dalam tradisi masyarakat Islam. Terkhusus berkaitan dengan hukum yang membolehkan seorang pria mempunyai empat istri sambil bisa mempertahankan kedamaian dan keharmonisan sekaligus. Bekerja selama setahun di sebuah badan hukum kemudian ditawarkan beasiswa oleh sahabatnya dari Iran untuk belajar hukum Islam di Universitas Teheran. Iran sebagai Negara muslim dengan tradisi dan hukum islam yang ketat, tentu akan sangat membantu proses belajarnya dalam mengamati dan mempelajari langsung hukum islam khususnya hukum keluarga Islam yang menarik minatnya. Terkhusus lagi Iran yang berkembang dengan tradisi peradaban Persia tentunya menjadi sumber inspirasi dan ketersediaan sumber informasi pengetahuan dan literatur islam.

Kuliahnya diawali selama 3 tahun dalam bahasa Persia dan menulis disertasi Ph.d dalam sastra Persia/literature persia tahun 1971 tentang Peranan Kaum Wanita (Haft Paykar) sebuah karya puisi oleh Nizhami. Disini dia belajar dan menyadari pra konspesinya yang semula di pelajari orang-orang Jepang dari sumber Barat, ternyata sama sekali tidak berkaitan dengan realitas masyarakat Iran. Kemudian ia transfer kuliah di fakultas Teologi, dimana ia menjadi satu-satunya perempuan pertama non muslim. Para temannya kebanyakan mullah dan salah satu gurunya adalah Prof. Abu Al Qasim Gurji yang merupakan murid terkemuka Ayatullah Khu'i.18 yang kemudian meyakinkannya bahwa akan beruntung mengambil mata kuliah tersebut.

Tutor privat beliau adalah Sayyid Hasan Iftikharzada Sabziwari, terididik dalam metodologi tradisional. Diajarkan menelaah dan mengkaji beberapa teks tersulit dari fiqih dan ushul fiqh disamping bimbingan professor Toshihiko Izutsu ${ }^{19}$.

Menetap di iran selama 12 tahun, Menyelesaikan Disertasi MA di Fakultas Teologi tentang Pernikahan Sementara (Mut'ah) pada tahun 1975 yang menarik minatnya dan pandangan beliau bahwa insitusi ini merupakan institusi yang realistis dan praktis dalam menghadapi penyakit sosial masa kini, khususnya dalam kehidupan di Barat, yang mana topik ini juga sengaja ditujukan terhadap stereotip Barat yang menganggap institusi ini tidak dapat diterima didunia manapun. Pada masa ini pula, ia memeluk agama Islam.

Tahun 1977 menulis disertasi perbandingan ajaran Islam dan Konghucu tentang keluarga, tetapi terputus karena Revolusi Islam Iran. yang mengantar dia dan suaminya, William chittick ${ }^{20}$ meninggalkan iran menuju new York, kemudian ia melanjutkan risetnya dalam tradisi intelektual, yaitu upaya memahami pemikiran Islam secara mendalam dengan kembali pada teks Al Qur'an dan hadist.

Tahun 1983 menetap di New York dan mengajar di Stony Brook. Department of Comparative Studies, State University of New York Kuliah pertama beliau tentang "Spiritualitas Feminin dalam Agama-agama Dunia". Begitu lekatnya perspektif mahasiswanya tentang prinsip Islam yang memakai perspektif Barat, menyulitkan beliau dalam mengenalkan prinsip-prinsip ajaran Islam. Sehingga terpaksa ia menggunakan perspektif Timur Jauh yaitu, pemikiran keagamaan Cina atau Taoisme

${ }^{18}$ Ayatullah Khu'i merupakan murid Ayatullah Sistani yang terkenal sangat konservatif dan salah satu marja' dalam mazhab syi'ah.

${ }_{19}$ Professor Toshihiko Izutsu terkenal sebagai pakar metafisika dan juga tradisi kearifan. Prof. Izutsu jugalah yang merintis adanya persamaan antara taoisme dan sufisme.

${ }^{20}$ Yang juga mempunyai kemampuan dan keahlian serta fokus studi pada bidang yang relative sama. Suaminya, William Chittick berkebangsaan Amerika merupakan seorang pemikir Islam dan mengkaji pemikiran Islam/ seorang tradisionalis. 
dan I Ching dalam mengkonsepsikan ajaran-ajaran Islam tentang prinsip feminine tanpa melanggar teks-teks asli.. Disini ia mendapati serangan mahasiswa menjadi reda, yakni. karena mahasiswa pada umumnya tidak punya prasangka buruk pada Taoisme, maka ketika Islam dijelaskan dalam kerangka Taoisme mereka akhirnya menjadi simpatik dan terbuka pada Islam.

Menjadi direktur pada Japanese Studies yang didirikan sejak 1990 dan aktif mengajar Studi Jepang, Budhisme Jepang, Spiritualitas Feminin dalam agama-agama Dunia dan juga kursus mengenai Islam dan Islam dan Konfusionisme. Beberapa tahun terakhir melakukan penelitian dan tulisannya mengenai "Muslim Konfusionis" dan lahirlah buku "The Tao of Islam" yang merupakan kitab rujukan relasi gender dalam teologi Islam, kosmologi dan psikologi spiritual dengan terminologi Neo Confusionis, Chinese Gleams of Sufi Light.

\section{KONSEP RELASI GENDER DALAM KOSMOLOGI DAN TEOLOGI ISLAM}

\section{Dualitas Ilahi}

Ketika "Tuhan" disebut-sebut dalam konteks pemikiran Islam, kata itu bisa dipahami dari dua sudut pandang. Yang pertama, kita bisa memandang Tuhan sebagai Dia dalam diri-Nya sendiri, di mana kita mengesampingkan kosmos, yakni segala sesuatu selain Tuhan. Dimensi inilah yang sebut dengan al-Ahadiyyah oleh Ibn 'Arabi. ${ }^{21}$ Dimensi ini direpresentasikan oleh nama-nama Keagungan/jalal/kualitas maskulin (masculine names) Tuhan. Pada dimensi ini seolah kita tidak akan pernah mungkin mengenal dan mengetahui Tuhan dalam diri-Nya sendiri, hanya sejauh Tuhan mengungkapkan diri-Nya. Hampir semua pemikir Muslim berkesimpulan bahwa Tuhan dalam diri-Nya sendiri, esensi (dzat) Tuhan tidak bisa diketahui. Dia tidak bisa kita pahami, ini mengantar kita pada perspektif ketakterbandingan Tuhan (tanzih). Ketakterbandingan Allah mengingatkan kita pada nama-nama seperti Maha Kuasa, Maha Tak-Terjangkau, Maha Besar, Maha Agung, Maha Pemaksa, Maha Pencipta, Maha Tinggi, Maha Raja, Maha Pemarah, Maha Pembalas, Maha Penghancur, Maha Pemusnah dan Maha Penyiksa. Nama-nama tersebut dinamakan sebagai "nama-nama yang", karena menekankan keagungan, kebesaran, kekuasaan, kontrol dan maskulinitas.

Kedua, jika kita menyebut-nyebut kosmos, maka kita mesti mempertimbangkan sejumlah hubungan yang terjalin antara Tuhan dan kosmos. Pada dimensi ini Tuhan dimungkinkan untuk diketahui, diidentifikasi, dan didefinisikan. Dimensi ini disebut alWahidiyyah oleh Ibn 'Arabi.22 Dimensi ini direpresentasikan oleh nama-nama keindahan/jamal/feminin (feminine names) Tuhan. Pada dimensi ini kita dimungkinkan untuk mengenal dan mendekati Tuhan, tidak pada diri-Nya sendiri, tetapi melalui lokus dimana Ia memanifestasikan diri-Nya. Kita bisa mengatakan bahwa ada keserupaan tertentu yang bisa diamati. Keserupaan Allah mengingatkan kita pada nama-nama Maha Indah, Maha Dekat, Maha Pengasih, Maha Penyanyang, Maha Kasih, Maha Lembut, Maha Pengampun, Maha Pemaaf, Maha Pemberi Hidup, Maha Pemberi Kekayaan, dan Maha Pemberi. Kesemuanya disebut "nama-nama yin", karena menekankan kepasrahan kepada kehendak dan keinginan pihak lain, kelembutan, penerimaan dan reseptivitas.

Di dalam Al-Qur'an diisyaratkan mekanisme dualitas makhluk makrokosmos yang dapat digunakan untuk memahami konsep dualitas Ilahi, antara lain dalam Q.S. alDzariyat :49

21 http://www.psq.or.id/index.php/in/component/content/article/94-tafsir/127-al-asmaul-al-huna-jendelauntuk-mengintip-tuhan. Akses 03 Mei 2011.

${ }^{22}$ Ibid. 


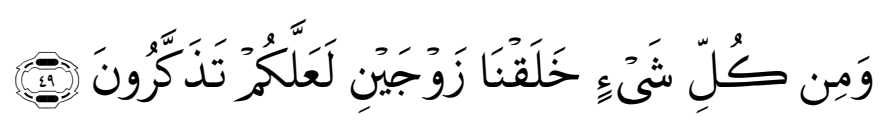

"Dan segala sesuatu Kami ciptakan berpasang-pasangan supaya kalian mengingat akan kebesaran Allah".

Redaksi serupa ini dapat ditemukan di beberapa ayat lainnya dalam Al-Qur'an. Makna zaujain di sini ialah Allah Swt menciptakan segala sesuatu berpasang-pasangan, yakni dengan dua realitas yang berbeda, namun saling melengkapi satu sama lain.

Dualitas Ilahi di sini sama sekali tidak ada maksud untuk mengusik konsep keesaan Allah Swt. Sebagai ilustrasi untuk dan demi memudahkan pemahaman, ibarat sebuah mata uang yang mempunyai dua sisih yang berbeda. Meskipun dua sisihnya berbeda bahkan mungkin kontras, tetapi tetap satau mata uang. Pada sebuah mata uang bisa saja pada satu sisihnya dapat dikenali karena terdapat nama dan angkanya. Akan tetapi pada sisihnya yang lain tidak dikenali karena memang tidak terdapat identitas yang dapat dikenali atau tertutup. ${ }^{23}$

Maskulitas dan feminitas pada tataran manusia masing-masing mempunyai sisi positif dan negatifnya, yang keduanya saling melengkakpi. Keseimbangan dan kesatuan yang dan yin, feminitas dan maskulinitas, jalal dan jamal sebagai tujuan penciptaan, selalu harus ditekankan dalam realitas kehidupan ini. Keseimbangan ini seharusnya tercipta baik di dalam alam lahiriah maupun bathiniah. Dengan kata lain, esensi tujuan hidup manusia baik laki-laki maupun perempuan adalah untuk menjadi insan kamil, yaitu manusia yang dapat menyatukan sisi ilahiah jamal dan jalal menjadi kamal (sempurna).

\section{Dua Tangan Allah}

Istilah "dua tangan Allah" muncul dalam QS. Shad: 75.

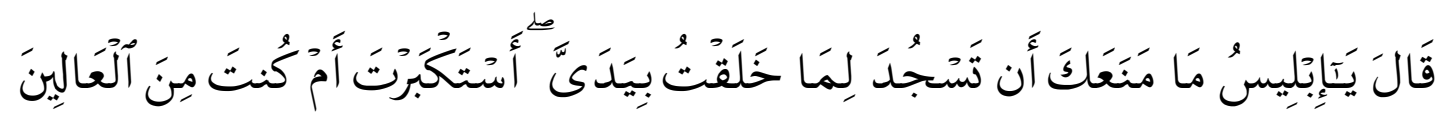

"Allah berfirman: "Hai iblis, apakah yang menghalangi kamu sujud kepada yang Telah Kuciptakan dengan kedua tangan-Ku. apakah kamu menyombongkan diri ataukah kamu (merasa) termasuk orang-orang yang (lebih) tinggi?".

Bagi kalangan tradisi hikmah, istilah dua tangan Tuhan itu dipandang sebagai salah satu simpul yang merangkum dan menyimpan banyak misteri dalam tataran hubungan antara manusia (mikrokosmos) dengan alam semesta (makrokosmos). Dua tangan Tuhan itu menunjuk kepada dua kategori nama-nama dan sifat-sifat Allah, yaitu sifat jalaliyyah dan sifat jamaliyyah. Sifat jalaliyyah adalah sifat-sifat Allah yang mencerminkan keagungan, kebesaran, kekuasaan, dan kekerasan-Nya. Sifat-sifat ini dikenal juga dengan sifat-sifat maskulin yang terungkap dalam nama-nama seperti al'Azhim, al-Qadir, dan al-Qahhar. Sedangkan sifat jamaliyyah adalah sifat-sifat yang mencerminkan kemurahan, kelembutan, kasih-sayang dan penerimaan-Nya. Sifat-sifat ini disebut juga sifat feminin Allah, seperti dalam nama-nama ar-Rahman, ar-Rahim, atTawwab, dan al-Ghafir. Dua kategori nama dan sifat Allah ini bekerja sedemikian rupa untuk mempertahankan alam semesta. Kendatipun aktualisasi nama-nama dan sifatsifat jalaliyyah (maskulin) cenderung tak tertahankan, terutama ketika Allah menunjukkan kekuasaan dan kekerasannya, misalnya dalam bentuk petaka dan

\footnotetext{
${ }^{23}$ Ibid.
} 
penderitaan manusia dan bencana alam, namun di balik semua itu, sesungguhnya sifatsifat jamaliyyah (feminin) yang lebih dominan pada diri Allah. ${ }^{24}$

\section{Langit dan Bumi}

Jika segala sesuatu diciptakan secara berpasang-pasangan, maka segala sesuatu selain Tuhan pastilah berpasangan, yaitu dibuat dari dualitas yang berbeda namun saling melengkapi. Pasangan yang paling sering disebut dalam Al-Qur'an yang dapat ditafsirkan sebagai gambaran keseluruhan kosmos adalah langit dan bumi. Setidaktidaknya dapat dikatakan bahwa langit dan bumi disebutkan sebagai dua titik acuan dasar di dunia ini. Misalnya:

QS. Az-Zukhruf : 84

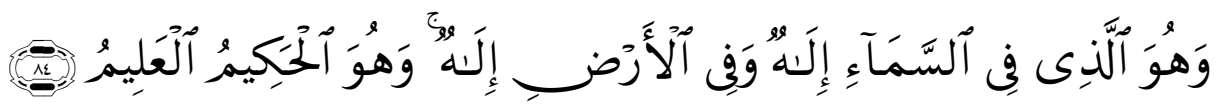

"Dan dialah Tuhan (yang disembah) di langit dan Tuhan (yang disembah) di bumi dan Dia-lah yang Maha Bijaksana lagi Maha Mengetahui."

QS. Ali Imran : 5

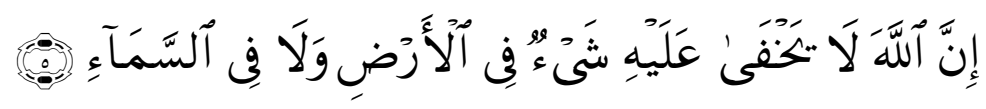

"Sesungguhnya bagi Allah tidak ada satupun yang tersembunyi di bumi dan tidak (pula) di langit."

Dan masih ada beberapa ayat lagi yang menjelaskan tentang langit dan bumi. Harus dicatat bahwa makna dasar dari kata sama' (langit) adalah yang lebih tinggi, lebih atas atau paling tinggi, paling atas, bagian dari segala sesuatu. Sebaliknya akar verbal dari kata $\operatorname{ardh}$ (bumi) berarti berusaha dan menghasilkan; membuahkan hasil, bersikap merendah, menyerah, secara alamiah terpanggil untuk berbuat baik. ${ }^{25}$

Nasafi memahami pasangan langit dan bumi sebagai yang menunjukkan jenis hubungan tertentu, yaitu memberi atau melimpahkan dan menerima atau menampung limpahan. Sementara segala sesuatu di antara keduanya mengacu pada hasil dari hubungan tersebut.

Langit adalah sesuatu yang tinggi dan memberikan limpahan pada satu tingkat dibawahnya.... Bumi adalah sesuatu yang relatif rendah dan menerima limpahan dari satu tingkat di atasnya....

Meskipun langit pelimpah dan bumi adalah penerima limpahan, tingkat bumi adalah di atas tingkatan langit. Jadi Hawa adalah di atas Adam.... ${ }^{26}$

Desakan Nasafi bahwa tingkat bumi ada di atas tingkat langit tampaknya berakar pada logika yang sama yang mendorong Ibn Al-Arabi mengatakan bahwa "tuan" tidak mungkin menjadi tuan tanpa adanya "budak", dan begitu pula "Tuhan" karena adanya eksistensi "hamba Ilahi”. Lebih-lebih, mitos penciptaan, Al-Qur'an menjelaskan bahwa Tuhan mula-mula mengalihkan perhatian-Nya pada bumi. Setelah membuatnya teratur, dia memisahkan langit:

QS. al-Baqarah : 29

24 M. Samsul Hadi, Pandangan Dunia Spiritual Islam dan Peran Sentral Manusia dalam Kosmos, Makalah disampaikan pada Annual Conference Departemen Agama, tanggal 26-30 t.t. di Lembang Bandung.

25 Sachiko Murata, The Tao of Islam: Kitab Rujukan tentang Relasi Gender dalam Kosmologi dan Teologi Islam, terj. Rahmani Astuti dan M. S. Nasrullah (Bandung: Mizan, 1998), hlm. 167.

${ }^{26}$ Ibid, hlm. 168. 


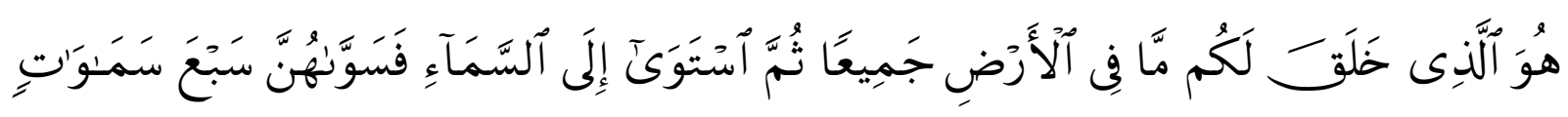

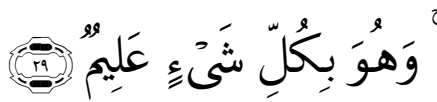

"Dia-lah Allah, yang menjadikan segala yang ada di bumi untuk kamu dan dia berkehendak (menciptakan) langit, lalu dijadikan-Nya tujuh langit. dan dia Maha mengetahui segala sesuatu."

QS. Fussilat : 9-12

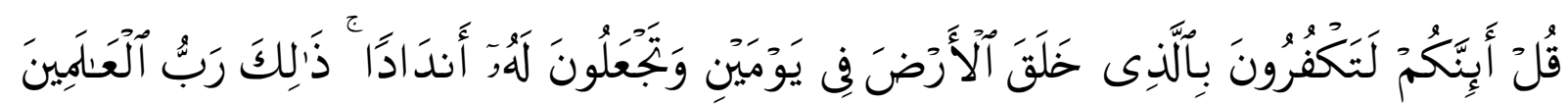

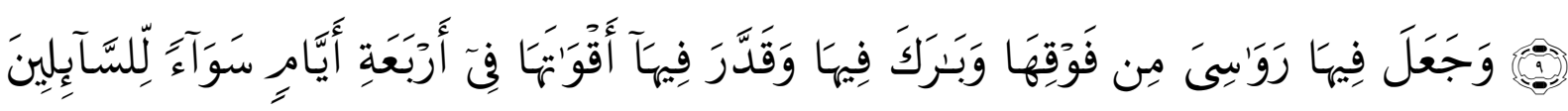

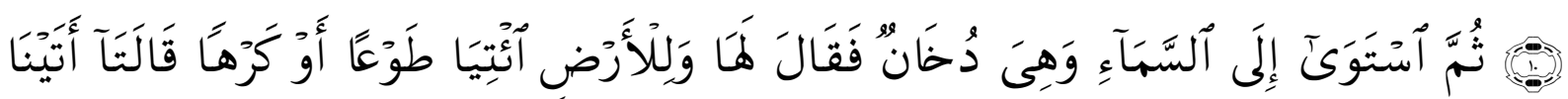

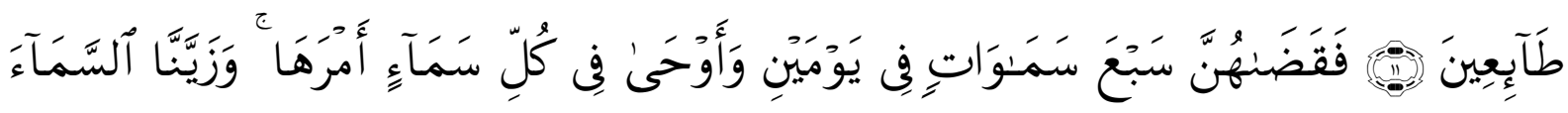

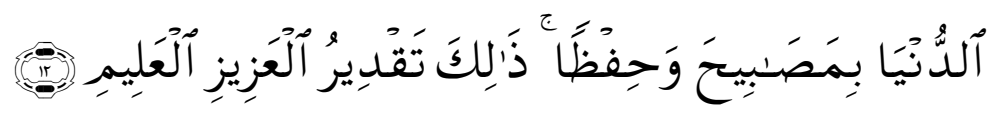

9. Katakanlah: "Sesungguhnya patutkah kamu kafir kepada yang menciptakan bumi dalam dua masa dan kamu adakan sekutu-sekutu bagi-Nya? (yang bersifat) demikian itu adalah Rabb semesta alam".

10. Dan dia menciptakan di bumi itu gunung-gunung yang kokoh di atasnya. dia memberkahinya dan dia menentukan padanya kadar makanan-makanan (penghuni)nya dalam empat masa. (Penjelasan itu sebagai jawaban) bagi orang-orang yang bertanya.

11. Kemudian dia menuju kepada penciptaan langit dan langit itu masih merupakan asap, lalu dia Berkata kepadanya dan kepada bumi: "Datanglah kamu keduanya menurut perintah-Ku dengan suka hati atau terpaksa". keduanya menjawab: "Kami datang dengan suka hati".

12. Maka dia menjadikannya tujuh langit dalam dua masa. dia mewahyukan pada tiaptiap langit urusannya. dan kami hiasi langit yang dekat dengan bintang-bintang yang cemerlang dan kami memeliharanya dengan sebaik-baiknya. Demikianlah ketentuan yang Maha Perkasa lagi Maha Mengetahui.

Al-Qur'an menyatakan secara jelas bahwa langit dan bumi ada secara bersamasama dalam keadaan yang tak terbedakan atau bersatu sebelum penciptaan.

QS. al-Anbiya': 30

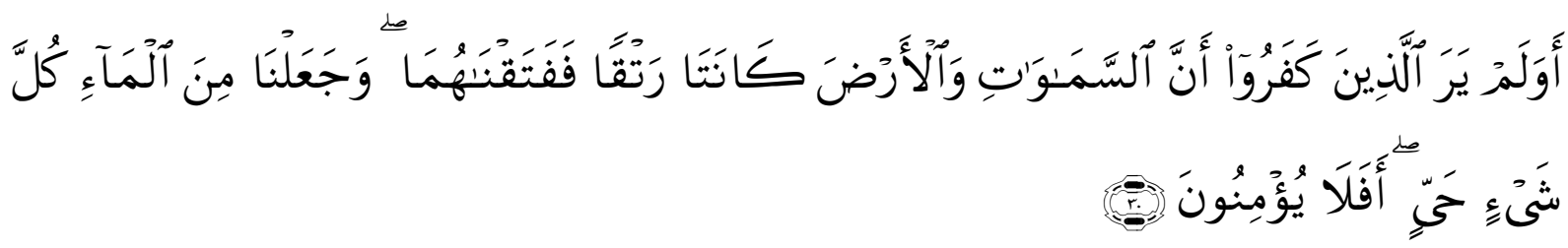


"Dan apakah orang-orang yang kafir tidak mengetahui bahwasanya langit dan bumi itu keduanya dahulu adalah suatu yang padu, Kemudian kami pisahkan antara keduanya. dan dari air kami jadikan segala sesuatu yang hidup. Maka mengapakah mereka tiada juga beriman?"

Seluruh kosmos berasal dari Tuhan, maka Tuhan mencintai alam semesta. Langit dan bumi tadinya sebongkah utuh, kemudian bumi dipisahkan dari langit, maka langit mencintai bumi dengan mencurahkan hujanya ke bumi. Dari diri Adam dipisahkan Hawa, maka Adam mencintai Hawa. Begitu pula Hawa akan cenderung kepada Adam, karena Adam adalah tempat di mana ia berasal.

\section{PERKAWINAN MAKROKOSMIK}

Hubungan antara langit dan bumi adalah hubungan antara yang dan yin, pria dan wanita, suami dan istri. Seperti baris-baris syair Rumi:

Dalam pandangan akal, langit adalah pria dan bumi adalah wanita

Apapun yang dijatuhkan oleh yang satu, akan terpelihara oleh yang lain ${ }^{27}$

Banyak teks yang menyebutkan suprioritas laki-laki di atas perempuan, seperti yang termaktub dalam al-Quran, surat Al-Baqoroh: 228

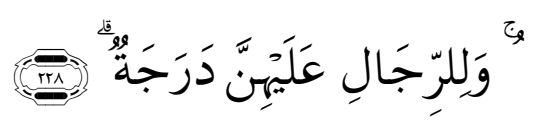

"Kaum lelaki satu derajat lebih tinggi daripada mereka (perempuan)".

Maybudi menerjemahkan keunggulan laki-laki terhadap perempuan dengan berbagai hak yang dimiliki laki-laki dan tidak dimiliki oleh perempuan. Di antaranya, hak menjadi imam sholat, hak memimpin rakyat, dan pergi berjihad, semua hak tersebut diberikan kepada laki-laki, berdasarkan pada kecerdasan dan agama. Laki-laki dianggap memiliki kecerdasan dan pemahaman agama yang lebih dibanding perempuan. selain itu, laki-laki berkewajiban memberi nafkah kepada istri dan anak-anaknya, dan laki-laki juga diizinkan menceraikan istrinya sedang kaum perempuan tidak mendapatkan izin tersebut. ${ }^{28}$

Ada beragam penafsiran terhadap ayat tersebut, sebagian orang mungkin menganggapnya sebagai bukti Islam mendiskriditkan perempuan. akan tetapi bagi mereka yang mengkajinya lebih mendalam akan beranggapan semuanya sebagai bukti kekuatan kaum perempuan yang menguasai masyarakat. Sachiko Murata berpendapat di satu sisi, perkataan-perkataan tersebut dimaksudkan untuk menekankan makna penting dari ikatan pernikahan sebagai pondasi umat. Mereka juga menetapkan hal-hal tertentu yang tidak dapat diubah dalam hubungan antara suami dan istri. Suami menyandang fungsinya sendiri, begitu pula sang istri juga menyandang fungsinya sendiri. ${ }^{29}$

Dalam surat Al-Baqoroh: 228 dijelaskan bahwa laki-laki memiliki tingkat lebih tinggi sering dijadikan legitimasi bahwa laki-laki lebih unggul dibanding perempuan. Akan tetapi Qusyairi mengatakan sifat kelemahan dan ketidakmampuan (sifat yin) yang biasa dilekatkan pada perempuan merupakan keadaan penghambaan yang sangat dibutuhkan dalam hubungannya dengan yang Nyata. Menurut Qusyairi kecenderungan laki-laki untuk menuntut kekuasaan dan kekhalifahan (yang), akan tetapi hal ini merupakan bahaya besar disebabkan mereka tidak mempunyai hak atasnya tanpa

\footnotetext{
${ }^{27}$ Ibid, hlm. 197.

${ }^{28}$ Ibid, hlm. hlm. 237-238.

${ }^{29}$ Ibid, hlm. hlm. 245.
} 
terlebih dahulu berada dalam keadaan sebagai seorang hamba. Sedangkan kaum perempuan mempunyai keuntungan dari kelemahannya yang relatif dan ketidak mampuannya di bidang lahiriah. Sehingga mereka tidak cenderung untuk membuat tuntutan yang tidak pada tempatnya. Mengakui sifat-sifat yin seseorang dihadapan Tuhan akan membantu menuju tauhid, sebab hal itu dapat membuat seseorang mengakui adanya kekuatan, kejayaan, penciptaan milik yang Nyata. ${ }^{30}$

Ada beragam penafsiran terhadap ayat tersebut, sebagian orang mungkin menganggapnya sebagai bukti Islam mendiskriditkan perempuan. akan tetapi bagi mereka yang mengkajinya lebih mendalam akan beranggapan semuanya sebagai bukti kekuatan kaum perempuan yang menguasai masyarakat. Sachiko Murata berpendapat di satu sisi, perkataan-perkataan tersebut dimaksudkan untuk menekankan makna penting dari ikatan pernikahan sebagai pondasi umat. Mereka juga menetapkan hal-hal tertentu yang tidak dapat diubah dalam hubungan antara suami dan istri. Suami menyandang fungsinya sendiri, begitu pula sang istri juga menyandang fungsinya sendiri. ${ }^{31}$

Ada beberapa ayat sering dipermasalahkan karena cenderung memberikan keutamaan kepada laki-laki, seperti dalam ayat warisan (QS. Al-Nis'a'/4: 11), persaksian (QS. Al-Baqarah/2:228, QS. Al-Nisa'/4:34), dan laki-laki sebagai "pemimpin"/qawwamah (QS. Al-Nisa'/4:34), akan tetapi ayat-ayat itu tidak bermaksud merendahkan kaum perempuan. Ayat-ayat itu boleh jadi merujuk kepada fungsi dan peran sosial berdasarkan jenis kelamin (gender roles) ketika itu. Seperti diketahui ayat-ayat mengenai perempuan umumnya mempunyai riwayat sabab nuzul jadi sifatnya sangat historical. Lagi pula ayat-ayat tersebut berbicara tentang persoalan detail (muayyidat). Umumnya ayat-ayat seperti itu dimaksudkan untuk mendukung dan mewujudkan tujuan umum (maqashid) ayat-ayat essensial, yang juga menjadi tema sentral Al-Qur'an. Ayat-ayat yang diturunkan dalam suatu sebab khusus (sabab nuzul) terjadi perbedaan pendapat di kalangan ulama, a) apakah ayat-ayat itu berlaku secara universal tanpa memperhatikan kasus turunnya (yufid al-'alm)?, atau b) berlaku universal dengan syarat memperhatikan persamaan karakteristik illat (khushush al-'illah), yang meliputi empat unsur yaitu peristiwa, pelaku, tempat, dan waktu?, atau c) hanya mengikat peristiwa khusus yang menjadi sebab (khushush al-sabab) turunnya ayat?, dengan demikian ayatayat tersebut tidak mengcover secara langsung peristiwa-peristiwa lain. ${ }^{32}$

Kedekatan dengan Tuhan yang dilakukan terus menerus akan memproses seseorang memperdalam spiritualitasnya. Proses kemerdekaan akan dialami ketika dirinya makin menyadari bahwa hanya Tuhan yang menguasai dirinya. Ia akan merasakan kekuatan muncul dari dalam dirinya (power within) dan yakin bahwa Tuhan selalu besertanya. Bagi perempuan yang berorientasi pada relasi, Ia akan mencari relasi dengan lingkungannya. Komunitas yang menyadari kekuatan personal ini akan berproses menjadi kekuatan komunitas (power with). Kekuatan komunitas inilah motor yang menggerakkan masyarakat untuk melakukan perubahan. ${ }^{33}$

${ }^{30}$ Spiritualitas Feminis Sebagai Roh Gerakan" diakses dari psp.ugm.ac.id/spiritualitas-feminis-sebagairoh-gerakan-perempuan.html-Akses 05 Mei 2011.

${ }^{31}$ Sachiko Murata, Op. cit, hlm. hlm. 238.

${ }^{32}$ http://www.scribd.com/doc/47802842/Argumen-Kesetaraan-Gender-Nasarudin-Umar. Akses 05 Mei 2011.

33 Rumi banyak berbicara tentang sosok seorang ibu. Kata "rahmah, belas kasih, akar kata dari namanama ilahi yang selalu diulang-ulang yaitu ar-rahman, "Yang Maha Pengasih", ar-rahim, "Yang Maha Penyayang", berasal dari akar yang sama yaitu rahim, "peranakan ibu". Rumi menggambarkan hubungan ibu dan anak seperti hubungan Tuhan dan hamba-Nya serta hubungan Nabi dengan umatnya. Rumi berkata, jika Tuhan adalah tempat berlindung umat manusia, maka ibu adalah tempat berlindung anaknya. Ketika Rumi menjalani kematian ekstase dalam cintanya, dia mengatakan: Seperti seorang anak yang mati di pangkuan ibunya, Begitu pula aku yang akan mati di pangkuan belas kasih. Annemarie Schimmel, Jiwaku adalah Wanita: Aspek Feminin dalam Spiritualitas Islam, hlm. 138-39. 
Perempuan memproses power within melalui penyadaran tubuh, dari aspek biologis dan spiritual. Mengapa demikian, karena selama ini baik budaya maupun agama masih memandang tubuh perempuan sebagai sasaran seks dan dianggap sumber dosa. Pandangan dikotomis jasmani-rohani masih merupakan pandangan arus utama Jasmani atau tubuh dikategorikan duniawi dan diberi nilai lebih rendah dari nilai rohani. Pandangan misoginis masih merupakan pandangan umum bagi laki-laki maupun perempuan. Tubuh perempuan yang oleh Sang Pencipta dianugerahi rahim, dimana kehidupan manusia baru berawal, seharusnya disadari sebagai kekuatan spesial bagi kehidupan. Perempuan wajib memperhatikan dan menyadari kekuatan yang diberikan Tuhan kepada mereka. Dari rahimlah kehidupan mulai dengan makanan jasmani dan rohani. Banyak penelitian menunjukkan bahwa situasi jasmani dan rohani ibu yang sedang hamil sangat mempengaruhi anak yang dikandung.34 Namun realitas hidup ini sekarang menjadi persoalan tersendiri bagi kaum perempuan.

Di atas telah dijelaskan bahwa sifat feminin yang ada pada diri perempuan memudahkan dalam proses penghambaan pada Tuhan. Sehingga perempuan lebih mudah dekat dengan Tuhan dibanding laki-laki. Akan tetapi hal ini bukan berarti mencoba mengunggulkan perempuan, dan menomor duakan laki-laki. Jika hal terjadi maka akan muncul problem, dengan masalah yang sama yaitu problem antara laki-laki dan perempuan. Hubungan antara laki-laki dan perempuan adalah hubungan yang saling melengkapi ${ }^{42}$ dan bukan hubungan yang saling dipertentangkan ataupun mempertentangkan.

Laki-laki dan perempuan sama-sama merupakan hamba Allah, yaitu sama-sama wajib menyembah Allah. Keduanya memiliki peluang dan potensi yang sama untuk menjadi hamba ideal. Dalam Al-Quran yang dimaksud dengan hamba ideal diistilahkan dengan "orang-orang yang bertakwa". Rumi mengatakan bahwa manusia sempurna tidak mempermasalahkan tentang jenis kelamin biologis. Sehingga keduanya dapat menjadi manusia sempurna, dalam hal ini dimaksud juga dengan hamba ideal, serta sama-sama memiliki peluang untuk mencapai prestasi spiritual. Tokoh perempuan yang mampu mencapai prestasi tersebut seperti: Maryam (ibunda nabi Isa), Khadijah, Aisyah, Ummu Salamah dan Hafsah binti Umar (keempatnya adalah istri Rasulullah), dan Robiah Al-Adawiyah (seorang sufi yang memiliki kelebihan sama atau bahkan melebihi lakilaki) dan masih banyak lagi contoh-contoh wanita Islam yang yang mempunyai prestasprestasi layaknya seorang pria.

\section{KESIMPULAN}

Banyak hal yang perlu diluruskan dalam persepsi masyarakat tentang perempuan. Terutama anggapan sadar dan bawah sadar bahwa kaum laki-laki lebih utama dari padakaum prempuan. Semenjak dahulu kala, orang banyak berbicara tentang ketimpangan sosial berdasarkan jenis kelamin tetapi hasilnya belum banyak mengalami kemajuan. Persepsi itu memang sulit dihilangkan karena berakar dari atau didukung oleh ajaran teologi. Padahal Max Weber pernah menegaskan bahwa tidak mungkin mengubah perilaku masyarakat tanpamengubah sistem etika, dan tidak mungkin mengubah etika tanpa meninjau sistem teologidalam masyarakat. Diskursus mengenai perempuan seringkali terlalu tematis, sehingga dilupakan persoalanasasinya. Para feminis telah banyak mencurahkan perhatian untuk mengangkat harkat danmartabat kaum perempuan, tetapi tidak sedikit perempuan merasa enjoy di atas keprihatinanpara feminis tersebut. Mereka percaya bahwa perempuan ideal ialah mereka yang bisa hidupdi atas kodratnya sebagai perempuan, dan kodrat itu dipahami sebagai takdir (divinecreation), bukan konstruksi masyarakat (social consttuction).

\footnotetext{
${ }^{34}$ Spiritualitas Feminis Sebagai Roh Gerakan" diakses dari psp.ugm.ac.id/spiritualitas-feminis-sebagairoh-gerakan-perempuan.html-Akses 05 Mei 2011.
} 


\section{DAFTAR PUSTAKA}

Dzuhayatin, Siti Ruhaini "Gender dalam Persfektif Islam: Studi terhadap Hal-hal yang Menguatkan dan Melemahkan Gender dalam Islam", dalam Mansour Fakih et al, 1996. Membincang Feminisme: Diskursus Gender Perspektif Islam, cet. I. Surabaya: Risalah Gusti.

Echols, John M. dan Shadily, Hassan. 1983. Kamus Inggeris Indonesia, cet. XII. Jakarta: Gramedia.

Hadi, M. Samsul. t.t Pandangan Dunia Spiritual Islam dan Peran Sentral Manusia dalam Kosmos, Makalah disampaikan pada Annual Conference Departemen Agama, tanggal 26-30 t.t. di Lembang Bandung.

http://www.scribd.com/doc/47802842/Argumen-Kesetaraan-Gender-NasarudinUmar. Akses 05 Mei 2011.

http://www.psq.or.id/index.php/in/component/content/article/94-tafsir/127-alasmaul-al-huna-jendela-untuk-mengintip-tuhan. Akses 03 Mei 2011.

Illich, Ivan. Gender, diterjemahkan oleh Omi Intan Naomi dengan judul Gender, cet. I (Yogyakarta: Pustaka Pelajar, 1998), hlm. 3.

Murata, Sachiko. 1998. The Tao of Islam: Kitab Rujukan tentang Relasi Gender dalam Kosmologi dan Teologi Islam, terj. Rahmani Astuti dan M. S. Nasrullah. Bandung: Mizan.

Neufeldt, Victoria (ed). 1984. Webster's New World Dictionary. New York: Webster's New World Clevenlan.

Spiritualitas Feminis Sebagai Roh Gerakan" diakses dari psp.ugm.ac.id/spiritualitasfeminis-sebagai-roh-gerakan-perempuan.html - Akses 05 Mei 2011.

Subhan, Zaitunah "Gender dalam Perspektif Islam”, dalam jurnal Akademika, vol. 06, No. 2, Maret, hlm. 128.

Tierney, Helen (ed). t.t. Women's Studies Encylopedia, vol. I. New York: Green Wood Press.

Umar, Nasaruddin. "Perspektif Gender dalam Islam", jurnal Paramadina, Vol. I. No. 1, Juli-Desember 1998, hlm. 99. 